\title{
STRATEGI KOMUNIKASI PEMERINTAH TERKAIT KEBIJAKAN LARANGAN MUDIK LEBARAN 2021
}

Penulis :
Institusi :
Email Korespondensi :
DOI

Kata Kunci:

Pemerintah

Komunikasi

Strategi Komunikasi

COVID-19

Keywords:

Government

Communication

Communication Strategy

COVID-19

\section{Hanggian Bayu Lestiyanto}

Fakultas Ilmu Sosial dan Ilmu Politik, Universitas Muhammadiyah Jakarta

hanggianbau@gmail.com

$10.53947 /$ perspekt.v1i2.29

\begin{abstract}
Abstrak
Adanya COVID-19 menyebabkan pemerintah melakukan penanggulangan pencegahan untuk mengurangi penyebaran virus COVID-19 berbagai upaya telah dilakukan pemerintah berupa kebijakan-kebijakan yang telah dibuat dan menjadi regulasi yang perlu ditaati oleh masyarakat. Liburan hari raya Idulfitri berkaitan erat dengan mobilitas penduduk dikarenakan adanya tradisi mudik di Indonesia, mobilitas penduduk yang terjadi pada saat dilaksakannya mudik ini dapat menjadi sarana penularan COVID-19 serta meningkatkan angka penyebaran kasus COVID-19 di Indonesia. Dalam rangka penanganan COVID-19, serta tingginya angka kasus penularan COVID-19 di Indonesia menjelang lebaran mengharuskan pemerintah memberlakukan suatu kebijakan larangan mudik lebaran tahun 2021 pada pandemi COVID-19. Pemerintah telah menetapkan kebijakan larangan mudik lebaran 2021 dengan maksud mengurangi penyebaran virus COVID-19. Strategi komunikasi dalam melaksanakan kebijakan larangan mudik lebaran 2021 dikomunikasikan kepada masyarakat dengan koordinasi yang tersusun oleh pihak terkait yang akan disampaikan kepada publik dengan isi pesan yang mempunyai tujuan dan maksud tertentu. Dalam mengkomunikasikan kepada masyarakat melalui media komunikasi dan media sosial agar dapat memengaruhi masyarakat untuk tidak melakukan mudik lebaran 2021 demi mencegah penyebaran COVID19. Penelitian ini menggunakan metode Studi Kepustakaan (Library Research) yang mana dalam penelitian ini tidak perlu terjun langsung kelapangan tetapi mengambil berbagai referensi yang mendukung dalampenelitian. Sumber data pada penelitian ini berupa buku, jurnal dan situs internet yang terkait dengan topik yang telah dipilih.
\end{abstract}


to the public through communication media and social media in order to influence the community not to go home for Eid 2021 in order to prevent the spread of COVID-19. This research uses the Library Research method which in this study does not need to go directly to the field but takes various references that support the research. The sources of data in this study are books, journals and internet sites related to the chosen topic.

\section{PENDAHULUAN}

Dalam rangka penanganan COVID-19 Indoneisa, pemerintah banyak memberlakukan berbagai kebijakan, seperti pemberlakuan Pembatasan Sosial Berskala Besar (PSBB), Work from Home (WFH), Pemberlakuan Pembatasan Kegiatan Masyarakat (PPKM). Selain pembatasan aktifitas di luar rumah, pembatasan untuk melakukan perjalanan pun dilakukan demi melindungi penyebaran COVID-19 yang semakin meluas, oleh karena itu pemerintah membuat suatu kebijakan larangan mudik pada hari raya lebaran tahun 2021. Kebijakan larangan mudik ini diatur dalam SE (surat edaran) Satuan Tugas Penanganan COVID19 Nomor 13 Tahun 2021 tentang Peniadaan Mudik Hari Raya Idulfitri 1442 Hijriah dan Upaya Pengendalian Penyebaran COVID-19 selama Bulan Suci Ramadhan 1442 Hijriah. Larangan mudik Lebaran 2021 berlaku pada 6-17 Mei 2021. Kebijakan pemerintah ini tampak sering berubah.

Seringnya kebijakan pemerintah yang berubah-ubah juga terkonfirmasi dalam beberapa survei. Salah satunya Survei Indo Barometer pada Mei 2020 yang memotret tingkat ketidakpuasan publik atas penanganan COVID-19 di masa JokowiMaruf Amin. Hasil survei tersebut menyebut 53,8 persen masyarakat tidak puas dengan kinerja pemerintah dalam penanganan
COVID-19. Faktor utamanya adalah kebijakan yang tidak konsisten (17,3 persen) serta kebijakan Presiden dan pembantunya sering berbeda ( 8,9 persen).

Sejarah inkosistensi inilah yang membuat masyarakat bersikap resisten saat pemerintah kembali mengeluarkan kebijakan mudik tahun ini. Terlebih, argumentasi yang disampaikan tidak jauh berbeda dengan alasan yang disampaikan saat melarang mudik tahun lalu, salah satunya kekhawatiran akan meningkatnya mobilitas atau pergerakan penduduk yang bisa berdampak pada meningkatnya jumlah kasus aktif. Coombs dalam Ongoing Crisis Communication (2007) menyebutkan pengalaman dan cara organisasi menyelesaikan krisis di masa lalu akan sangat mempengaruhi penilaian publik terhadap komumikasi pemerintah dalam menyelesaikan masalah. Dalam situasi krisis seperti pandemi COVID-19, crisis history (sejarah krisis) dan prior reputation (reputasi awal) pemerintah menjadi tolok ukur bagi masyarakat untuk mengikuti atau menolak kebijakan yang dikeluarkan pemerintah. Tolok ukur inilah juga yang digunakan masyarakat dalam menyikapi kebijakan larangan mudik yang disampaikan pemerintah.

Melalui SE No. 13 Tahun 2021 pemerintah tegas melarang masyarakat untuk 
melakukan kegiatan mudik lebaran demi mencegah penularan COVID-19. Larangan ini diberlakukan untuk moda transportasi darat, laut dan udara. Satgas Penanganan COVID-19 bersama jajaran pemerintah terkait di antaranya Kementerian Perhubungan dan Polri, mengumumkan hal ini dalam agenda keterangan pers perkembangan penanganan COVID-19 dan sosialisasi ketetapan pengendalian COVID19 selama bulan suci ramadhan dan hari raya Idulfitri 1442 H. Dalam kesempatan tersebut, Juru Bicara Satgas Penanganan COVID-19 Wiku Adi sasmito, bersama Kakorlantas Polri Irjen Istiono beserta jajaran Kemenhub di antaranya Dirjen Perhubungan Darat Budi Setiadi, Dirjen Perhubungan Laut Agus H Purnomo, Dirjen Perkeretaapian Zulfikri yang diwakili oleh Danto Restyawan Direktur Lalu Lintas dan Angkutan Kereta Api, Dirjen Perhubungan Udara Novie Riyanto Raharjo dan Juru bicara Kementerian Perhubungan Adita Irawati.

Dengan demikian pemerintah mengkomunikasikan kembali secara jelas dan tegas mengenai pengendalian penyebaran COVID-19 di antaranya adalah menegaskan protokol kesehatan. Kebijakan PPKM upaya saat ini yang sedang dilakukan dalam Pengetatan perjalanan berpergerian. Selain itu pemerintah juga perlu melakukan strategi komunikasi kepada masyarakat mengenai kebijakan ini agar masyarakat lebih memahami dan menjadi sadar diri akan penting kebijakan ini dalam mencegah penularan virus kembali meningkat, karena komunikasi memiliki peran sangat penting dalam memberikan informasi dan mencegah atau menurunkan keinginan masyarakat untuk pulang kekampung halaman pada Idulfitri 2021 ini.

\section{KAJIAN LITERATUR}

\section{Strategi Komunikasi}

Strategi komunikasi terdiri dari dua suku kata yaitu strategi dan komunikasi. Istilah strategi sudah menjadi istilah asing yang sering digunakan oleh masyarakat untuk menggambarkan berbagai makna seperti suatu rencana, taktik atau cara untuk mencapai apa yang diinginkan. Strategi pada hakekatnya adalah perencanaan (planning) dan manajemen (management) untuk mencapai suatu tujuan (Effendy, 2018).

\section{Komunikasi Pemerintahan}

Menurut Erliana Hasan, Komunikasi Pemerintahan adalah Penyampaian ide, program, dan gagasan pemerintah kepada masyarakat dalam rangka mencapai tujuan negara. Dalam hal ini pemerintah dapat diasumsikan sebagai komunikator dan masyarakat sebagai komunikan, namun dalam suasana tertentu bisa sebaliknya masyarakat berada pada posisi sebagai penyampai ide atau gagasan dan pemerintah berada pada posisi mencermati apa yang diinginkan masyarakat (Hasan \& Gunarsa, 2005).

\section{Strategi Komunikasi Pemerintah}

Setiap kegiatan komunikasi harus berdasarkan rencana atau strategi komunikasi yang terdiri dari elemen-elemen dasar yaitu:

1) Menentukan tujuan komunikasi

2) Menentukan target komunikasi.

3) Menentukan pesan yang akan disampaikan.

4) Menentukan waktu yang tepat. 


\section{Hambatan Komunikasi Pemerintahan}

Garnett dan Kouzmin dalam

Handbook of Administrative Communication menyebutkan hambatan-hambatan komunikasi pemerintahan, yaitu hambatan bahasa, kerangka referensi, jarak status, jarak geografis, perlindungan diri dari inisiator, tekanan pekerjaan lainnya, dan pembatasan yang disengaja pada komunikasi (Garnett \& Kouzmin, 1997).

\section{Landasan Teori}

Harold Lasswell, Komponen dan indikator strategi komunikasi meliputi (Lasswell, 1971):

1) Who? (siapakah komunikatornya). Sejumlah indikator yang berhubungan dengan komponen strategi komunikasi ini mencakup kepercayaan diri, kredibilitas, terbuka, jujur, disiplin, berkeinginan keras, penuh perhitungan logika dan rasional, selalu mawas diri.

2) Says what? (pesan apa yang dinyatakan) Sejumlah indikator yang berhubungan dengan komponen strategi komunikasi ini mencakup benar, autentik, rasional, terukur, banyak, 13 valid, reliabel, cepat, jelas sumbernya, selalu menjadi sumber pemerkaya pesan lainnya.

3) In which channel? (Media apa yang digunakan) Sejumlah indikator yang berhubungan dengan komponen strategi komunikasi ini mencakup elektronik, cetak, grafis gambar, infografis, visual diam, visual gerak, audio, audio visual.

4) To whom? (siapa komunikannya). Sejumlah indikator yang berhubungan dengan komponen strategi komunikasi ini mencakup personal, kelompok terbatas, masyarakat luas, lawan tujuan, pertemanan dalam satu tujuan, anggota baru, bukan anggota organisasi, anggota lama, orang yang membutuhkan laporan.

5) With what effect? (efek apa yang diharapkan) Sejumlah indikator yang berhubungan dengan komponen strategi komunikasi ini mencakup pemahaman pesan oleh komunikan, kerjasama dalam mema hami pesan, terjalin pemahaman bersama, terjadinya perbedaan persepsi, ingin menunjukan arah dari pesan, memberikan pesan yang dimaksud, bertambahnya persepsi baru yang sesuai, bertambahnya persepsi baru yang bertentangan, saling memperkaya pemahaman pesan, berorientasi pada pencapaian tujuan bersama dengan pesan yang sama, berorientasi pada capaian tujuan yang sama dengan pesan yang berbeda (Effendy, 2018).

Penelitian ini bermaksud mengungkapkan serta mendeskripsikan tentang bagaimana strategi komunikasi pemerintah dala kebijakan larangan mudik lebaran 2021. Teori yang digunakan untuk meneliti fenomena penelitian ini adalah teori Harold Laswell.

\section{METODE PENELITIAN}

Menurut Suradika salah satu cakupan penelitian adalah upaya yang terencana mencari informasi yang belum diketahui (Suradika, 2000). Pada penelitian ini digunakan metode Studi Kepustakaan (Library Research). Menurut Zed penelitian studi kepustakaan adalah serangkaian kegiatan yang berkenaan dengan metode pengumpulan data pustaka, membaca dan mencatat, serta mengelolah bahan penelitian (Zed, 2008). Penelitian ini tidak diperlukan kegiatan lapangan secara langsung akan tetapi dengan referensi yang diambil untuk penelitian ini berupa buku, jurnal, situs internet yang tekait dengan bahasan dalam penelitian. Teknik pengumpulan data berdasarkan hasil kerangka berpikir peneliti. 


\section{HASIL DAN PEMBAHASAN}

Berdasarkan kebijakan larangan mudik yang dilakukan oleh pemerintah adalah komunikasi terhadap masyarakat sebagai perintah dan bentuk ajakan tidak melakukan mudik lebaran 2021 dan bersama menghindari penyebaran virus COVID-19. Dalam membangun komunikasi pemerintah terlebih dahulu memberitahukan pihak-pihak yang terkait sesuai susunan koordinasi dengan jajaran yang terkait antara lain Satgas Penanganan COVID-19, Kakorlantas Polri Irjen, Kementerian perhubungan, Dirjen Perhubungan Darat, Dirjen Perhubungan Laut, Dirjen Perhubungan Udara, Dirjen Perkeretaapian, Lalu lintas dan Angkutan Kereta Api dan Pemerintah daerah tentang adanya kebijakan larangan mudik lebaran 2021 yang akan disosialisasikan kepada masyarakat.

Pesan yang disampaikan oleh pemerintah pusat dan pemerintah daerah melaui media online dan arahan pemerintah daerah setempat mengenai larangan mudik lebaran 2021 untuk mencegah penularan COVID-19. Pelarangan mudik ini merupakan bentuk upaya pemerintah dalam mencegah penyebaran COVID-19 untuk perjalanan mudik dikecualikan bagi kendaraan pelayanan distribusi logistic dan pelaku perjalanan dengan keperluan mendesak untuk kepentingan nonmudik, yaitu bekerja/perjalanan dinas, kunjungan keluarga sakit/meninggal, ibu hamil dan kepentingan persalinan. Namun, pelaku perjalanan juga harus mendapatkan izin tertentu dengan memiliki SKIM (Surat Izin Keluar Masuk) sebagai persyaratan perjalanan. Namun ada pula pengecualian kendaraan yang masih boleh melanjutkan perjalanan berlaku bagi kendaraan pimpinan kembaga tertinggi negara dan kendaraan bernomor plat dinas TNI/Polri. Pengawasan ketat juga dilakukan pihak kepolisian dalam pengamanan sampai 17 Mei 2021. Sosialisai kebijakan pelarangan mudik 2021 harus dilakukan secara massif agar terbentuk pemahaman bahwa langkah yangdiambil pemerintah itu demi kepentingan bersama.

Komunikasi terkait kebijakan larangan mudik disampaikan dengan melakukan komunikasi langsung pada masyarakat dan melalui media elektronik seperti radio, media sosial seperti Facebook, Twitter, Instagram, WhatsApp, berita online, televisi dan radio. Pemerintah juga membuat poster atau spanduk terkait mengajak masyarakat untuk tidak melakukan mudik lebaran 2021 di berbagai titik lokasi yang dianggap strategis dekat terminal, lampu merah dan jalan protocol.

Dampak dari adanya kebijakan larangan mudik lebaran 2021 membuat masyarakat sebagian kecil untuk memilih mudik sebelum tanggal 6 Mei 2021 atau sesudah hari raya lebaran menghindari arus mudik yang bersamaan karena menimbulkan peningkatan penyebaran virus COVID-19. Tetapi masih ada masyarakat yang belum bisa menerima peraturan kebijakan yang ditetapkan oleh pemerintah dan tetap berkeinginan melakukan mudik lebaran hal ini bisa dilihat dari lebaran tahun sebelumnya 2020 masih banyak masyarakat yang tetap melakukan mudik lebaran dan tidak menerapkan protokol kesehatan. Namun dengan upaya yang dilakukan oleh 
pemerintah dan melihat dari lebaran tahun lalu pemerintah bekerja lebih ekstra dan melakukan strategi baru untuk masyarakat paham akan kebijakan yang dimaksud.

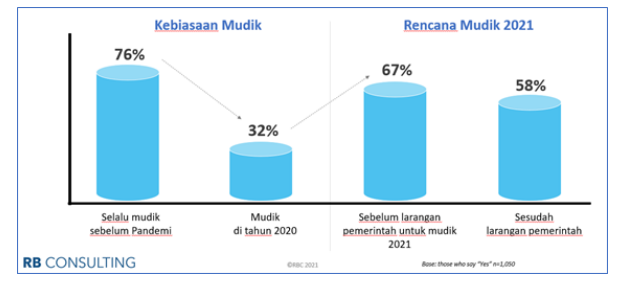

Bagan 2 Survey Pemudik

\section{KESIMPULAN}

Dengan adanya pandemic COVID-19 pemerintah mengeluarkan kebijakankebijakan yang selalu berubah-ubah guna mengurangi penyebaran COVID-19 mulai dari PSBB, Larangan Mudik, PPKM, dll. Sehingga masyarakat merasakan untuk menjalani kebijakan tersebut. Kebijakan larangan mudik 2021 telah dikomunikasikan oleh pemerintah yang tertuang pada SE No. 13 Tahun 2021 pemerintah tegas melarang masyarakat untuk melakukan kegiatan mudik lebaran demi mencegah penularan COVID19. Larangan ini diberlakukan untuk moda transportasi darat, laut dan udara. Namun, ada pengecualian bagi yang memiliki SKIM dan kepentingan tertentu yang sudah ditetapkan. Dalam membangun komunikasi pemerintah terlebih dahulu memberitahukan pihak-pihak yang terkait sesuai susunan koordinasi dengan jajaran yang terkait antara lain Satgas Penanganan COVID-19, Kakorlantas Polri Irjen, Kementerian perhubungan, Dirjen Perhubungan Darat, Dirjen Perhubungan
Laut, Dirjen Perhubungan Udara, Dirjen Perkeretaapian, Lalu lintas dan Angkutan Kereta Api dan Pemerintah daerah tentang adanya kebijakan larangan mudik lebaran 2021 yang akan disosialisasikan kepada masyarakat.

\section{Saran}

Berdasarkan kesimpulan diatas maka diperlukan strategi komunikasi yang baik dari pemerintah dalam memberikan informasi mengenai kebijakan larangan mudik melalui koordinasi semua pihak tidak hanya dengan pihak pejabat yang terkait melainkan juga komunikasi melalui pendekatan preventif dengan masyarakat melalui sosialisasi kebijakan ditingkat daerah dengan sumber daya daerah masyarakat setempat.

\section{REFERENSI}

Effendy, O. U. (2018). Ilmu komunikasi. In Bandung Rosdakarya. PT Remaja Rosdakarya Offset.

Garnett, J. L., \& Kouzmin, A. (1997). Handbook of administrative communication. In Public administration and public policy (Issue 63). Marcel Dekker.

Hasan, E., \& Gunarsa, A. (2005). Komunikasi pemerintahan. Refika Aditama.

Lasswell, H. D. (1971). The Process and Effects of Mass Communication. University of Illinois Press.

Suradika, A. (2000). Metode Penelitian Sosial. UMJ Press.

Zed, M. (2008). Metode penelitian kepustakaan. Yayasan Obor Indonesia. 